\title{
PENGARUH GREEN MARKETING DAN MARKETING MIX TERHADAP CUSTOMER PREFERENCE DAN DAMPAKNYA TERHADAP KEPUTUSAN PEMBELIAN \\ (Studi pada Mahasiswa S2 Konsumen Aqua-Danone, Fakultas Ilmu Administrasi Universitas Brawijaya. Malang)
}

\author{
Any Riswati Suharyono Srikandi Kumadji \\ Fakultas Ilmu Administrasi Universitas Brawijaya Malang \\ Email: anyriswati90@gmail.com
}

\begin{abstract}
Green marketing is the concept of green marketing that is friendly to nature and environmental sustainability, green marketing is defined as a management process responsible for identifying, anticipating and satisfying the needs of consumers is profitable and sustainable (Peattie, 1992). Aqua Danone uses green marketing strategy as environmentally friendly marketing strategy shaft successful, because aqua have an environmental policy "Ground Water Policy" in managing the environment. Supported by the marketing mix strategy as the best communication tool for consumers in determining the choice of eco-friendly products before deciding to buy and consume products that benefit consumers and the environment. This study uses path analysis (path analysis) along with hypothesis testing to determine significant influence on the variables that are already defined. Population taken from S2 FIA UB student consumer Danone Aqua, with a sample of 75 people with the questionnaire data collection techniques shoot one study. The results of green marketing on customer preference significantly, green marketing is not a significant influence on purchasing decisions, marketing mix insignificant effect on customer preferences, marketing mix significantly influence purchase decisions, and customer preferences significantly influence purchasing decisions. The study was limited to one-shoot-study used data. Future research is expected to use this type of qualitative research in order to know in detail the impact of products on the environment in the long term.
\end{abstract}

Keyword : green marketing, marketing mix, customer preference, and purchasing decisions.

\begin{abstract}
ABTRAK
Green marketing merupakan konsep pemasaran hijau yang ramah terhadap kelestarian alam dan lingkungan, green marketing didefinisikan sebagai suatu proses manajemen yang bertanggung jawab untuk mengidentifikasi, mengantisipasi dan memuaskan kebutuhan dari konsumen secara profitable dan berkelanjutan (Peattie,1992). Aqua Danone menggunakan strategi green marketing sebagai poros strategi pemasaran ramah lingkungan yang sukses, karena aqua memiliki kebijakan lingkungan "Water Ground Policy" dalam mengelola lingkungan. Didukung dengan adanya strategi marketing mix sebagai alat komunikasi yang terbaik untuk konsumen dalam menentukan pilihan terhadap produk ramah lingkungan sebelum akhirnya memutuskan untuk membeli dan mengkonsumsi produk yang menguntungkan bagi konsumen dan lingkungan. Tujuan dalam penelitian ini untuk mengetahui dan menjelaskan pengaruh signifikan green marketing dan marketing mix terhadap customer preference. Mengetahui dan menjelaskan pengaruh signifikan green marketing dan marketing mix terhadap keputusan pembelian. Mengetahui dan menjelaskan customer preference terhadap keputusan pembelian. Penelitian ini menggunakan metode analisis jalur (path analysis) disertai dengan pengujian hipotesis guna mengetahui pengaruh signifikan terhadap variabel yang sudah ditentukan. Populasi yang diambil dari mahasiswa S2 FIA UB konsumen Aqua Danone, dengan sampel sebanyak 75 orang dengan teknik pengambilan data angket one shoot study. Hasil penelitian menunjukkan pengaruh green marketing terhadap customer preference signifikan, green marketing berpengaruh tidak signifikan terhadap keputusan pembelian, marketing mix berpengaruh tidak signifikan terhadap customer preference, marketing mix berpengaruh signifikan terhadap keputusan pembelian, dan customer preference berpengaruh signifikan terhadap keputusan pembelian. Penelitian ini terbatas dengan menggunakan data one shoot study. Penelitian yang akan datang diharapkan dapat menggunakan jenis penelitian kualitatif guna mengetahui secara mendetail dampak produk terhadap lingkungan dalam jangka panjang.
\end{abstract}

Kata kunci : green marketing, marketing mix, customer preference, dan keputusan pembelian. 


\section{PENDAHULUAN}

Kesadaran masyarakat dunia akan pentingnya pelestarian lingkungan semakin meningkat, peningkatan ini dimungkinkan karena adanya kekhawatiran terjadinya bencana hidup yang mengancam kesehatan dan kelangsungan hidup manusia dan keturunannya. Bukti-bukti tersebut ditunjukkan para ilmuwan dan pemerhati lingkungan, seperti penipisan lapisan ozon yang secara langsung memperbesar prevelensi kanker kulit dan berpotensi mengacaukan iklim dunia serta pemanasan global, memperkuat alasan kekhawatiran tersebut. Belum lagi masalah hujan asam, efek rumah kaca, polusi udara dan air yang sudah pada taraf berbahaya, kebakaran dan penggundulan hutan yang mengancam jumlah oksigen di atmosfir kita dan banjir di sejumlah kota. Situasi seperti itu akhirnya munculah apa yang disebut green consumerism. Green consumerism adalah kelanjutan dari gerakan konsumerisme global yang dimulai dengan adanya kesadaran konsumen akan hak- haknya untuk mendapatkan produk yang layak, aman, dan produk yang ramah lingkungan (environment friendly) yang semakin kuat. Situasi tersebut memunculkan adanya kesadaran tersebut maka perusahaan menerapkan isu-isu lingkungan sebagai salah satu strategi pemasarannya atau yang telah kita kenal sebagai green marketing.

Beberapa penelitian tentang pemasaran hijau dikatakan bahwa environmental atau green marketing (pemasaran hijau) merupakan fokus baru dalam usaha bisnis, yaitu sebuah pemasaran statejik yang mulai mencuat dan menjadi perhatian banyak orang mulai abad 20. Kondisi seperti ini menuntut pemasar untuk berhati-hati dalam memutuskan memasarkan produk yang melibatkan lingkungan. Green marketing sebagai poros 
konsep pemasaran hijau yang ramah lingkungan yang sukses dalam memotivasi konsumen melalui customer preference guna mempengaruhi keputusan pembelian dengan mengunakan stategi marketing mix.

\section{Rumusan Masalah}

1) Apakah green marketing berpengaruh signifikan terhadap pilihan konsumen?

2) Apakah green marketing berpegaruh signifikan terhadap keputusan pembelian?

3) Apakah marketing mix berpengaruh signifikan terhadap pilihan konsumen?

4) Apakah marketing mix berpengaruh signifikan terhadap keputusan pembelian?

5) Apakah pilihan konsumen berpengaruh signifikan terhadap keputusan pembelian.

\section{Tujuan Penelitian}

1) Mengetahui dan menjelaskan pengaruh green konsumen. marketing terhadap pilihan

2) Mengetahui dan menjelaskan pengaruh green marketing terhadap keputusan pembelian.

3) Mengetahui dan menjelaskan pengaruh marketing mix terhadap pilihan konsumen.

4) Mengetahui dan menjelaskan pengaruh marketing mix terhadap keputusan pembelian.

5) Mengetahui dan menjelaskan pengaruh pilihan konsumen terhadap keputusan pembelian.

\section{LATAR BELAKANG TEORI DAN HIPOTESIS}

\section{Pemasaran}

Pemasaran adalah suatu sistem keseluruhan dari kegiatan-kegiatan bisnis

yang ditujukan untuk merencanakan, menentukan haprga, mempromosikan, dan mendistribusikan barang dan jasa yang memuaskan kebutuhan baik kepada pembeli yang ada maupun pembeli potensial.

Pemasaran memiliki dua hal. Pertama, pemasaran merupakan filosofi, sikap, perspetif atau orientasi manajemen yang menekankan pada kepuasan konsumen. Kedua, pemasaran adalah sekumpulan aktivitas yang digunakan untuk mengimplementasikan filosofi ini. Definisi dari American Marketing Association (AMA) mencakup kedua perspektif itu: "Marketing is the process of planning and executing the conception, pricing, promotion, and distribution of ideas, goods, and services to create exchange that satisfy individual and organizational goals". Artinya bahwa pemasaran merupakan suatu proses perencanaan dan menjalankan konsep, harga, promosi, dan distribusi sejumlah ide, barang, dan jasa untuk menciptakan pertukaran yang mampu memuaskan tujuan individu dan organisasi.

\section{Green marketing (Pemasaran Hijau)}

Green marketing (pemasaran hijau) sebagai salah satu usaha strategis dalam menciptakan bisnis yang berbasis lingkungan dan kesehatan telah dikenal pada akhir tahun 1980-an dan awal 1990- an. American Marketing Associate (AMA) mendefinisikan green marketing is the marketing of products that are presumed to be environmentally safe (sebagai suatu proses pemasaran produk-produk yang diasumsikan aman terhadap lingkungan).

\section{Green Product (Produk Hijau)}

Junaedi (2005) mendefinisikan, produk hijau (Green product) adalah produk yang tidak berbahaya bagi manusia dan lingkungannya, tidak boros sumber daya, tidak menghasilkan sampah berlebihan, dan tidak melibatkan kekejaman pada binatang. Green product harus mempertimbangkan aspek-aspek lingkungan dalam siklus hidup produk sehingga dapat meminimalkan dampak negatif terhadap alam. Upaya minimalisasi tersebut untuk mendorong semua pihak agar berperan dalam pengembangan teknologi menuju produk ramah lingkungan. Pada sektor produksi, berbagai macam cara dapat dilakukan guna menghasilkan suatu produk yang ramah lingkungan yaitu salah satunya dengan menggunakan konsep green product yang berkelanjutan. Green product adalah upaya untuk meminimalkan limbah ketika proses produksi di samping memaksimalkan produk yang dibuat sekaligus memenuhi syarat ramah lingkungan. Green product sendiri harus mempunyai kualitas produk yang tahan lama dalam artian tidak mudah rusak, tidak mengandung racun, dibuat dari 
bahan yang dapat di daur ulang dan memiliki packaging yang minimalis.

\section{Green Consumerism}

Green consumerism sebagai

kelanjutan dari gerakan konsumerisme

global yang dimulai dari adanya kesadaran

konsumen akan hak-haknya untuk mendapatkan produk yang layak dan aman sehingga tuntutan terhadap produk yang ramah lingkungan semakin kuat. Sedangkan Green consumers memiliki keyakinan bahwa ada problem lingkungan yang nyata, problem tersebut harus ditangani dengan serius dan disikapi dengan cara yang aktif, mereka merasa mendapatkan informasi yang cukup dalam keseharian hidup mereka, setiap individu dapat dan harus memberikan kontribusi dalam menyelamatkan bumi dari bencana lingkungan yang menakutkan (Grant, 2003).

\section{Strategi Marketing Mix (Bauran Pemasaran) \\ strategi bauran pemasaran merupakan kombinasi variabel atau kegiatan yang merupakan inti dari sistem pemasaran, variabel yang dapat dikendalikan oleh perusahaan untuk mempengaruhi reaksi para pembeli atau konsumen. Kotler (2005) mengemukakan bauran pemasaran adalah seperangkat alat pemasaran yang digunakan perusahaan untuk terus-menerus mencapai tujuan pemasarannya di pasar sasaran. Cravens}

(2000) menyatakan bauran pemasaran mengacu pada paduan strategi produk, distribusi, promosi dan penentuan harga yang bersifat unik yang dirancang untuk menghasilkan pertukaran yang saling memuaskan dengan pasar yang dituju.

\section{Customer Preference}

Konsumen memproses informasi tentang

produk didasarkan pada pilihan

merek untuk membuat keputusan terakhir,

timbulnya pembelian suatu produk terlihat dimana konsumen mempunyai kebutuhan yang ingin dipuaskan. Konsumen akan mencari informasi tentang manfaat produk dan selanjutnya mengevaluasi atribut produk tersebut. Konsumen akan memberikan bobot yang berbeda untuk setiap atribut produk sesuai dengan kepentingannya, dari sini akan menimbulkan preferensi konsumen terhadap merek yang ada. Preferensi konsumen adalah sesuatu yang lebih disukai dan dipilih oleh konsumen sebagai pilihan utamanya. Preferensi tersebut adalah bergantung pada barang dan layanan yang baik.

\section{Keputusan Pembelian}

Keputusan pembelian konsumen adalah karakteristik orientasi mental yang dihadapkan konsumen untuk membuat suatu pilihan (Sproles \& Kendal, 1986). Dengan perkataan lain pilihan alternatif harus tersedia bagi seseorang ketika mengambil keputusan. Jika seorang konsumen dihadapkan antara dua pilihan merek atau produk yang akan dibeli, maka orang tersebut dalam posisi untuk mengambil keputusan pembelian.

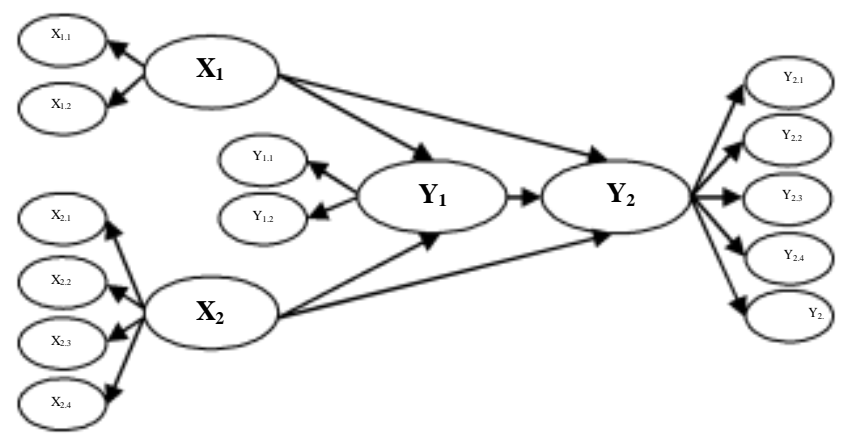

Keterangan:

$\mathrm{X}_{1}$ : Green Marketing

$\mathrm{X}_{1.1}$ : Green Product

$\mathrm{X}_{1.2}$ : Green Consumerism

$\mathrm{X}_{2}$ : Marketing Mix

$\mathrm{X}_{2.1}$ : Produk

$\mathrm{X}_{2.2}:$ Harga

$\mathrm{X}_{2.3}$ : Saluran Distribusi

$\mathrm{X}_{2.4}$ : Promosi

$\mathrm{Y}_{1}$ : Customer Preference

$Y_{1.1}$ : Konsumen Menimbang Bobot Produk Dilihat Dari Atribut Produk

$\mathrm{Y}_{1.2}$ : Dampak Produk Terhadap lingkungan

$Y_{2}$ : Keputusan Pembelian

$\mathrm{Y}_{2.1}$ : Keputusan Tentang Jenis Produk

$\mathrm{Y}_{2.2}$ : Keputusan Tentang Bentuk Produk

$\mathrm{Y}_{2.3}$ : Keputusan tentang Merek

$\mathrm{Y}_{2.4}$ : Keputusan Tentang Pembeliannya

$\mathrm{Y}_{2.5}$ : Keputusan Tentang Jumlah Produk 


\section{Kerangka Konseptual}

Kerangka Konseptual merupakan model tentang bagaimana teori berhubungan dengan berbagai faktor yang telah diidentifikasi sebagai masalah yang penting menurut (Sapto Haryoko dalam Iskandar, 2008). Penelitian ini menguji pengaruh green marketing dan marketing mix terhadap customer preference dan dampaknya terhadap keputusan pembelian.

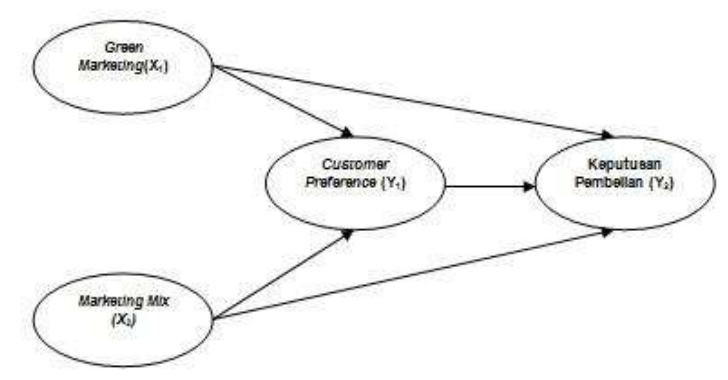

\section{Hipotesis}

$\mathrm{H}_{1}$ : Green marketing berpengaruh signifikan terhadap customer preference

$\mathrm{H}_{2}$ :Green Marketing berpengaruh signifikan terhadap keputusan pembelian

$\mathrm{H}_{3}$ :Marketing Mix berpengaruh signifikan terhadap customer preference

$\mathrm{H}_{4}$ :Marketing Mix berpengaruh signifikan terhadap keputusan pembelian

$\mathrm{H}_{5}$ :Customer preference berpengaruh signifikan terhadap keputusan pembelian

\section{METODE PENELITIAN}

\section{Jenis Penelitian}

Explanatory research yang menjelaskan hubungan kausal antara variabel-variabel penelitian melalui pengujian hipotesis. Sedangkan pendekatan yang digunakan pada penelitian ini adalah pendekatan kuantitatif.

\section{Lokasi dan Sampel Penelitian}

Fakultas Ilmu Administrasi Universitas Brawijaya dipilih peneliti sebagai lokasi penelitian, kriteria responden yaitu Mahasiswa S2 FIA UB konsumen Aqua Danone. Waktu penelitian adalah studi satu tahap (one-shot study) Merupakan penelitian yang datanya dikumpulkan sekaligus dalam satu periode waktu.

Populasi dalam penelitian ini adalah keseluruhan Mahasiswa S2 FIA UB konsumen Aqua Danone. Jumlah sampel

dalam penelitian ini berjumlah 75 responden, berdasarkan rumus Machin and Campbell (1987).
Variabel Penelitian

Variabel independen:Green Marketing (x1) dan Marketing Mix (x2).

Variabel Dependen :Pilihan Konsumen (Y1) dan Keputusan Pembelian (Y2)

\section{Skala Pengukuran}

Dalam penelitian ini jawaban responden dalam kuesioner diukur menggunakan Skala Likert (Likert Scale)

\section{Metode Analisis Data}

Analisis Deskriptif

Analisis deskriptif digunakan untuk mengungkap gambaran data yang telah dikumpulkan dari lokasi penelitian, pendeskripsian dapat dilakukan dengan cara pengolahan data melalui tabulasi guna mengungkapkan kecenderungan data nominal empirik seperti rata-rata hitung. Hasil analisis deskriptif akan diinterpretasikan guna mendukung penafsiran atau hasil analisis dengan teknik lainnya.

\section{Analisis Path}

Analisis path digunakan untuk menguji hipotesis penelitian. Analisis jalur ini digunakan untuk mendapatkan hasil penelitian yang representatif.

\section{Hasil Uji Validitas dan Reliabilitas}

\section{Tabel 1 : Hasil Uji Validitas}

\begin{tabular}{|c|c|c|c|c|c|}
\hline Variabel & Indikator & Item & $\mathbf{R}$ & Sig & Ket \\
\hline \multirow{8}{*}{$\begin{array}{c}\text { Green } \\
\text { Marketing } \\
\left(\mathrm{X}_{1}\right)\end{array}$} & \multirow{5}{*}{$\begin{array}{l}\text { Green } \\
\text { Product } \\
\left(\mathrm{X}_{1.1}\right)\end{array}$} & $\mathrm{X}_{1.1 .1}$ & 0,871 & 0,000 & Valid \\
\hline & & $\mathrm{X}_{1.1 .2}$ & 0,776 & 0,000 & Valid \\
\hline & & $X_{1.1 .3}$ & 0,812 & 0,000 & Valid \\
\hline & & $X_{1.1 .4}$ & 0,746 & 0,000 & Valid \\
\hline & & $X_{1.1 .5}$ & 0,705 & 0,000 & Valid \\
\hline & \multirow{3}{*}{$\begin{array}{c}\text { Green } \\
\text { Consumeri } \\
\text { sm } \\
\left(\mathrm{X}_{1.2}\right)\end{array}$} & $X_{1.2 .1}$ & 0,849 & 0,000 & Valid \\
\hline & & $X_{1.2 .2}$ & 0,857 & 0,000 & Valid \\
\hline & & $\mathrm{X}_{1.2 .3}$ & 0,718 & 0,000 & Valid \\
\hline \multirow{4}{*}{$\begin{array}{c}\text { Marketin } \\
\text { g Mix } \\
\left(\mathrm{X}_{2}\right)\end{array}$} & \multirow{4}{*}{$\begin{array}{c}\text { Produk } \\
\left(\mathrm{X}_{2.1}\right)\end{array}$} & $X_{2.1 .1}$ & 0,837 & 0,000 & Valid \\
\hline & & $X_{2.1 .2}$ & 0,592 & 0,000 & Valid \\
\hline & & $\mathrm{X}_{2.1 .3}$ & 0,705 & 0,000 & Valid \\
\hline & & $\mathrm{X}_{2.1 .4}$ & 0,625 & 0,000 & Valid \\
\hline
\end{tabular}




\begin{tabular}{|c|c|c|c|c|c|}
\hline & \multirow{3}{*}{$\begin{array}{c}\text { Harga } \\
\left(\mathrm{X}_{2.2}\right)\end{array}$} & $X_{2.2 .1}$ & 0,637 & 0,000 & Valid \\
\hline & & $X_{2.2 .2}$ & 0,802 & 0,000 & Valid \\
\hline & & $X_{2.2 .3}$ & 0,883 & 0,000 & Valid \\
\hline & \multirow{3}{*}{$\begin{array}{l}\text { Saluran } \\
\text { Distribusi } \\
\left(\mathrm{X}_{2.3}\right)\end{array}$} & $X_{2.3 .1}$ & 0,746 & 0,000 & Valid \\
\hline & & $X_{2.3 .2}$ & 0,891 & 0,000 & Valid \\
\hline & & $X_{2.3 .3}$ & 0,845 & 0,000 & Valid \\
\hline & \multirow{3}{*}{$\begin{array}{l}\text { Promosi } \\
\left(\mathrm{X}_{2.4}\right)\end{array}$} & $X_{2.4 .1}$ & 0,780 & 0,000 & Valid \\
\hline & & $X_{2.4 .2}$ & 0,922 & 0,000 & Valid \\
\hline & & $X_{2.4 .3}$ & 0,854 & 0,000 & Valid \\
\hline \multirow{6}{*}{$\begin{array}{c}\text { Custom } \\
\text { er } \\
\text { Preferen } \\
\text { ce } \\
\left(\mathrm{Y}_{1}\right)\end{array}$} & \multirow{3}{*}{$\begin{array}{c}\text { Atribut } \\
\text { Produk } \\
\left(\mathrm{Y}_{1.1}\right)\end{array}$} & $Y_{1.1 .1}$ & 0,681 & 0,000 & Valid \\
\hline & & $Y_{1.1 .2}$ & 0,852 & 0,000 & Valid \\
\hline & & $Y_{1.1 .3}$ & 0,649 & 0,000 & Valid \\
\hline & \multirow{3}{*}{$\begin{array}{c}\text { Dampak } \\
\text { Terhadap } \\
\text { Lingkunga } \\
n \\
\left(Y_{1.1}\right)\end{array}$} & $Y_{1.2 .1}$ & 0,739 & 0,000 & Valid \\
\hline & & $Y_{1.2 .2}$ & 0,841 & 0,000 & Valid \\
\hline & & $Y_{1.2 .3}$ & 0,679 & 0,000 & Valid \\
\hline \multirow{14}{*}{$\begin{array}{c}\text { Keputus } \\
\text { an } \\
\text { Pembeli } \\
\text { an } \\
\left(Y_{2}\right)\end{array}$} & \multirow{3}{*}{$\begin{array}{c}\text { Jenis } \\
\text { produk } \\
\left(\mathrm{Y}_{2.1}\right)\end{array}$} & $Y_{2.1 .1}$ & 0,722 & 0,000 & Valid \\
\hline & & $Y_{2.1 .2}$ & 0,901 & 0,000 & Valid \\
\hline & & $Y_{2.1 .3}$ & 0,768 & 0,000 & Valid \\
\hline & \multirow{3}{*}{$\begin{array}{c}\text { Bentuk } \\
\text { Produk } \\
\left(\mathrm{X}_{2.2}\right)\end{array}$} & $Y_{2.2 .1}$ & 0,783 & 0,000 & Valid \\
\hline & & $Y_{2.2 .2}$ & 0,778 & 0,000 & Valid \\
\hline & & $Y_{2.2 .3}$ & 0,751 & 0,000 & Valid \\
\hline & \multirow{2}{*}{$\begin{array}{c}\text { Merek } \\
\left(\mathrm{X}_{2.3}\right)\end{array}$} & $Y_{2.3 .1}$ & 0,935 & 0,000 & Valid \\
\hline & & $Y_{2.3 .2}$ & 0,944 & 0,000 & Valid \\
\hline & \multirow{3}{*}{$\begin{array}{c}\text { Pembelian } \\
\left(\mathrm{X}_{2.4}\right)\end{array}$} & $Y_{2.4 .1}$ & 0,866 & 0,000 & Valid \\
\hline & & $Y_{2.4 .2}$ & 0,864 & 0,000 & Valid \\
\hline & & $Y_{2.4 .3}$ & 0,856 & 0,000 & Valid \\
\hline & \multirow{3}{*}{$\begin{array}{c}\text { Jumlah } \\
\text { Produk } \\
\left(\mathrm{X}_{2.5}\right)\end{array}$} & $Y_{2.5 .1}$ & 0,868 & 0,000 & Valid \\
\hline & & $Y_{2.5 .2}$ & 0,908 & 0,000 & Valid \\
\hline & & $Y_{2.5 .3}$ & 0,920 & 0,000 & Valid \\
\hline
\end{tabular}

kemasan. Aqua adalah sebuah merek air minum dalam kemasan (AMDK) yang diproduksi oleh PT Aqua Golden Mississippi di Indonesia sejak tahun 1973. Selain di Indonesia, Aqua juga dijual di Singapura. Aqua adalah merek AMDK dengan penjualan terbesar di Indonesia dan merupakan salah satu merek AMDK yang paling terkenal di Indonesia, sehingga telah menjadi seperti merek generik untuk AMDK. Saat ini, terdapat 14 pabrik yang memproduksi Aqua dengan kepemilikan berbeda-beda (10 pabrik dimiliki oleh PT Tirta Investama, 3 pabrik dimiliki oleh PT Aqua Golden Mississippi, dan pabrik di Brastagi, Sumatera Utara dimiliki oleh PT Tirta Sibayakindo). Sejak tahun 1998, Aqua sudah dimiliki oleh perusahaan multinasional dalam bidang makanan dan minuman asal Perancis, Grup Danone, hasil dari penggabungan PT Aqua Golden Mississippi dengan Danone. Aqua Danone menggunakan strategi green marketing sebagai poros strategi pemasaran ramah lingkungan yang sukses, karena aqua memiliki kebijakan lingkungan Water Ground Policy dalam mengelola lingkungan.

Tabel 2 : Hasil Uji Reliabilitas

\begin{tabular}{|c|c|c|}
\hline Variabel & Koefisien Alpha & Keterangan \\
\hline $\begin{array}{c}\text { Green } \\
\text { Marketing } \\
\left(\mathrm{X}_{1}\right)\end{array}$ & 0,835 & Reliabel \\
\hline $\begin{array}{c}\text { Marketing } \\
\text { Mix }\left(\mathrm{X}_{2}\right)\end{array}$ & 0,766 & Reliabel \\
\hline $\begin{array}{c}\text { Customer } \\
\text { Preference } \\
\left(\mathrm{Y}_{1}\right)\end{array}$ & 0,777 & Reliabel \\
\hline $\begin{array}{c}\text { Keputusan } \\
\text { Pembelian } \\
\left(\mathrm{Y}_{2}\right)\end{array}$ & 0,871 & \\
\hline
\end{tabular}

\section{HASIL DAN PEMBAHASAN Gambaran}

\section{Umum Perusahaan}

Group Danone adalah perusahaan multinasional yang memproduksi berbagai jenis makanan dan minuman. Danone mengklaim sebagai pemimpin di pasar produk turunan susu dan air minum dalam 
Hasil Analisis (Path Analysis)

Tabel 3 Hasil Analisis Path

\begin{tabular}{|c|c|c|c|c|c|}
\hline $\begin{array}{l}\text { Indep } \\
\text { enden }\end{array}$ & $\begin{array}{c}\begin{array}{c}\text { Depen } \\
\text { den }\end{array} \\
\end{array}$ & Beta & $\mathbf{T}$ & Sig $t$ & $\begin{array}{c}\text { Keterang } \\
\text { an }\end{array}$ \\
\hline$X_{1}$ & \multirow[t]{2}{*}{$Y_{1}$} & 0,564 & 5,704 & 0,000 & Signifikan \\
\hline$X_{2}$ & & 0,190 & 1,926 & 0,058 & $\begin{array}{c}\text { Tidak } \\
\text { Signifikan }\end{array}$ \\
\hline$X_{1}$ & \multirow{3}{*}{$\mathrm{Y}_{2}$} & 0,024 & 0,215 & 0,830 & $\begin{array}{c}\text { Tidak } \\
\text { Signifikan }\end{array}$ \\
\hline$X_{2}$ & & 0,493 & 5,130 & 0,000 & Signifikan \\
\hline$Y_{1}$ & & 0,326 & 2,918 & 0,005 & Signifikan \\
\hline
\end{tabular}

Keterangan Tabel :

$\mathrm{X}_{1} \quad$ : Green Marketing

$\mathrm{X}_{2} \quad$ : Marketing Mix

$\mathrm{Y}_{1} \quad$ : Customer Preference

$\mathrm{Y}_{2}$ : Keputusan Pembelian

\section{Hasil Pengujian Hipotesis}

Tabel 4 Hasil Pengujian Hipotesis

\begin{tabular}{|c|c|c|c|c|}
\hline $\begin{array}{c}\text { Variabel } \\
\text { Bebas }\end{array}$ & $\begin{array}{c}\text { Variabel } \\
\text { Terikat }\end{array}$ & $\begin{array}{c}\text { Koefisien } \\
\text { beta }\end{array}$ & $\begin{array}{c}\mathbf{p}- \\
\text { value }\end{array}$ & Keterangan \\
\hline $\mathrm{X}_{1}$ & $\mathrm{Y}_{1}$ & 0,564 & 0,000 & Signifikan \\
\hline $\mathrm{X}_{1}$ & $\mathrm{Y}_{2}$ & 0,024 & 0,830 & $\begin{array}{c}\text { Tidak } \\
\text { Signifikan }\end{array}$ \\
\hline $\mathrm{X}_{2}$ & $\mathrm{Y}_{1}$ & 0,190 & 0,058 & $\begin{array}{c}\text { Tidak } \\
\text { Signifikan }\end{array}$ \\
\hline $\mathrm{X}_{2}$ & $\mathrm{Y}_{2}$ & 0,493 & 0,000 & Signifikan \\
\hline $\mathrm{Y}_{1}$ & $\mathrm{Y}_{2}$ & 0,326 & 0,005 & Signifikan \\
\hline
\end{tabular}

Keterangan Tabel :

$\mathrm{X}_{1} \quad$ : Green Marketing

$\mathrm{X}_{2} \quad$ : Marketing Mix

$\mathrm{Y}_{1} \quad$ : Customer Preference

$\mathrm{Y}_{2}$ : Keputusan Pembelian

Apabila :

$p$-value $<0,05=\mathrm{H}_{0}$ ditolak

$p$-value $>0,05=\mathrm{H}_{0}$ diterima

\section{Hasil Analisis Jalur (Path) Secara Keseluruhan}

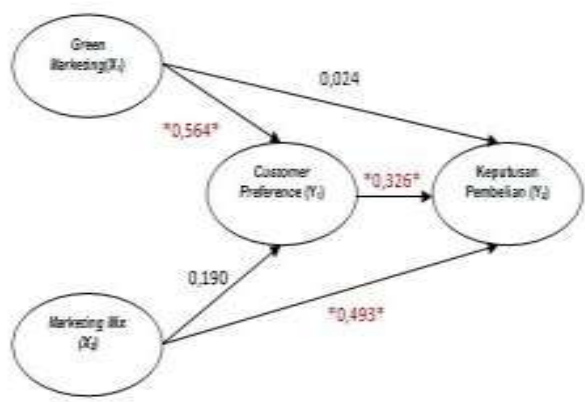

\section{Tabel 5: Hubungan Antar Variabel}

\begin{tabular}{|c|c|c|c|}
\hline $\begin{array}{c}\text { Variabel } \\
\text { Bebas }\end{array}$ & $\begin{array}{c}\text { Variabel } \\
\text { Terikat }\end{array}$ & $\begin{array}{c}\text { Koefisien } \\
\text { jalur }\end{array}$ & Keterangan \\
\hline $\mathrm{X}_{1}$ & $\mathrm{Y}_{1}$ & 0,564 & Signifikan \\
\hline $\mathrm{X}_{1}$ & $\mathrm{Y}_{2}$ & 0,024 & $\begin{array}{c}\text { Tidak } \\
\text { Signifikan }\end{array}$ \\
\hline $\mathrm{X}_{2}$ & $\mathrm{Y}_{1}$ & 0,190 & $\begin{array}{c}\text { Tidak } \\
\text { Signifikan }\end{array}$ \\
\hline $\mathrm{X}_{2}$ & $\mathrm{Y}_{2}$ & 0,493 & Signifikan \\
\hline $\mathrm{Y}_{1}$ & $\mathrm{Y}_{2}$ & 0,326 & Signifikan \\
\hline
\end{tabular}

Keterangan Tabel :

$\mathrm{X}_{1} \quad$ : Green Marketing

$\mathrm{X}_{2} \quad$ : Marketing Mix

$\mathrm{Y}_{1} \quad$ : Customer Preference

$\mathrm{Y}_{2} \quad$ : Keputusan Pembelian

\section{KESIMPULAN DAN SARAN \\ Kesimpulan}

Berdasarkan analisis, pembahasan hasil penelitian serta pengujian hipotesis yang dilakukan sebagaimana telah di uraikan sebelumnya maka dapat disimpulkan sebagai berikut.

1. Green marketing memiliki pengaruh signifikan tehadap Customer preference.

Hal ini disebabkan konsumen mulai

selektif dalam memilih produk yang mempunyai konsep ramah lingkungan.

2. Green marketing memiliki pengaruh tidak signifikan terhadap keputusan pembelian. Hal ini disebabkan kuputusan pembelian produk oleh konsumen tidak hanya berdasarkan konsep produk yang ramah lingkungan, melainkan terdapat faktor lain yang mempengaruhinya.

3. Marketing mix memiliki pengaruh yang tidak signifikan terhadap customer

preference. Hal ini disebabkan karena strategi marketing mix tidak dapat mempengaruhi konsumen melalui customer preference.

4. Marketing mix berpengaruh signifikan terhadap keputusan pembelian. Hal ini disebabkan keputusan pembelian oleh konsumen dipengaruhi oleh strategi marketing mix dari segi produk, harga, saluran distribusi dan promosi.

5. Customer preference berpengaruh signifikan terhadap keputusan pembelian. Hal ini disebabkan pilihan konsumen akan berpengaruh secara langsung terhadap keputusan pembelian. 


\section{Saran}

Penelitian ini masih mungkin untuk dikembangkan dalam menguji ulang model penelitian dengan menambah variabel- variabel baru. Penelitian mendatang diharap mampu mengembangkan konseptual dan permodelan kajian penelitin ini pada objek-objek kajian penelitian yang lebih luas dengan tetap pada skema konsep green marketing perusahaan melalui strategi marketing mix guna meningkatkan tingkat signifikasi terhadap customer preference dan keputusan pembelian.

\section{DAFTAR PUSTAKA}

American Marketing Asociate. (AMA).1975. Pengertian green marketing. http://www.flickr.com/photos/cali2okie/ 2399377732/). Diakses 29 Maret 2014.

Charter, M. 1992. Greener marketing: a Responsible Approach to Bussiness. Greenleaf: Sheffield.

Craven, D.W. 2000. "Strategic Marketing", 6th ed. Boston:Massachusetts: Irwin/McGraw-Hill.

Ferdinand, Augusty. 2003. Sustainable Competitive Advantage: Sebuah Eksplorasi Model Konseptual. BP Undip.

Ferdinand, A. 2006. "Metode Penelitian Manajemen: Penelitian Untuk Penulisan Skripsi, Tesis dan Disertasi Ilmu Manajemen". Badan Penerbit Universitas Diponegoro, Semarang.

Grant, R.M. 2003. "The Greening of Business: The Role of Green Consumerism, the limits of Earth". Department of Marketing, University of Southern California.

Grant, John. 2007. The Green Marketing Manifesto. John Wiley \& Sons, Ltd., West Sussex, England. Journal of Business Ethics, Vol. 29.

Haryadi, Rudi. 2009. Pengaruh Green Marketing Terhadap Pilihan
Konsumen Melalui Pendekatan Marketing Mix (Studi Kasus Pada The Body Shop Jakarta). Tesis. Program Studi Magister Management-Program Pascasarjana Universitas Diponegoro.

Junaedi, S.M.F. 2005, "Pengaruh Kesadaran Lingkungan pada Niat Beli Produk Hijau: Studi Perilaku Konsumen Berwawasan Lingkungan," Benefit Jurnal Manajemen dan Bisnis, Vol. 9, No. 2, hal. 189-201.

Kalafatis, S., Pollard, M., East, R. and Tsogas, M.H. 1999, "Green marketing and Ajzen's theory of planned behaviour: a crossmarket examination", Journal of Consumer Marketing, Vol. 16 No. 5, pp. 441-60.

Kasali, Rhenald. 2005. "Sembilan Fenomena Bisnis", Manajemen Student Society MSS, FEUI official Site.

Kotler, P. 2000. “Manejemen Pemasaran”. Jilid 1,Edisi Millenium, Alih Bahasa: Hendra Teguh, Rony A. Rusly \& Drs.Benyamin Molan, Penerbit, Prentice Hall \& Pearson Education Asia, Jakarta.

Kotler, Philip \&Amstrong, Gary. 2001. Principle of Marketing (9th Ed.) New Jersey: Prentice Hall Inc.

Kotler, P. 2003. "A Generic Concept of Marketing". Journal of Marketing Vol. 36 No. 2.

Kotler, P. 2005. "Manejemen Pemasaran".

Alih Bahasa: Drs.Benyamin Molan. Jilid I. Index Kelompok Gramedia, Jakarta.

Laroche, M., J. Bergeron, G. Barbaro- Forleo, 2001, "Targeting consumers who are willing to pay more for environmentally friendly products", Journal of Consumer Marketing, 18, 6, 503-520.

Malhotra, N. K. 2005. "Riset Pemasaran, Pendekatan Terapan”, Edisi Keempat. Penerbit Indeks, Jakarta. 
Nugrahadi, E.W. 2002. "Pertanian Organik Sebagai Alternatif teknologi Dalam Upaya Menghasilkan Produk Hijau", www.google.com.

Ottman, J.A. 1994. "Green Marketing: Challenges and Opportunities for the New Marketing Age", NTC Publishing Group, Lincolwood.

Ottman, J.A., et al., 2006. "Green Marketing Myopia : Ways to Improve Consumer Appeal for Environmentally Preferable Products". Environment Volume 48, Number 5 pp 22-36 Heldref Publications, 2006.

Ottman, J.A., et al. 2011. "Green Marketing: Challenges and Opportunities For The New Marketing Age". NTC Business Books, Lincolnwood.

Peattie, Ken. 1992. Green Marketing (1st Ed.) UK: Longman Group.

Polonsky, Michael Jay. 1994. An

Introduction To

Marketing. Electronic

Journal . Vol 1 issue 2.

Polonsky, M.J, Rosenberger, P.J and
Schiffman, L.G and Kanuk, L.L.,2007. "Perilaku Konsumen", Edisi 7, Alih bahasa, Zoelkifli Kasip, Penyunting Bahasa, Rita Maharani, Penerbit PT Indeks, Jakarta.

Sekaran, U., 2006, "Research Methods for Business", Buku 1, Edisi 4, Penerjemah Kwan Men Yon, Penerbit Salemba Empat.

Sekaran, U., 2006, "Research Methods for Business", Buku 2, Edisi 4, Penerjemah Kwan Men Yon, Penerbit Salemba Empat.

Solimun. 2002. "Metode Kuantitatif Untuk Manajemen", Diktat Kuliah Program Pascasarjana Universitas Brawijaya, Malang.

Stanton, W.J. 1991. "Fundamental of Marketing". McGraw-Hill Book Company, New York.

Wibowo, Buddi. 2002. Green Consumerism

dan Green Marketing:

\footnotetext{
PerkembanganPerilauKonsumendan

PendekatanPemasaranUsahawan. No. 6 Th XXXI Juni, pp: 12-15. Ottman, J, 1998, “ Developing Green

Products: Learning From Stakeholder,' Asia Pacific Journal or Marketing anc Logistics, 10 (1), 2243.
}

Riduwan, dan Kuncoro. 2007. "Analisis Jalur Path Analysis: Cara Menggunakan dan Memakai". Cetakar Kedua, Penerbit, Alfabeta.

Sarwono, J. 2007. "Analisis Jalur Untuk Riset Bisnis Dengan SPSS". Penerbil Andi, Yogyakarta.

Schiffman, Leon G. \&Kanuk, Leslie Lazar. 2004. PerilakuKonsumen (ZoelkifliKasip, PenerjemahEdisiKetujuh). Jakarta: Indeks. 
Internet

http://www.aqua.com/

http://www.danone.com/en/for-

all/our-4- business-

lines/waters/our- brands/buid/aqua/

http://id.wikipedia.org/wiki/Aqua

\%28air_mi neral\%29

http://info-

biografi.blogspot.com/2013/0

3/sejarah-

berdirinya-aqua.html

http://www.aqua.com/tentang_a

qua/nilai-

luhur 